\title{
PERSEPSI GURU TERHADAP PENGGUNAAN BUKU AJAR NIHONGO KIRAKIRA DALAM PEMBELAJARAN BAHASA JEPANG BERBASIS KURIKULUM 2013 DI SMA KOTA SINGARAJA
}

\author{
S.D. Fanani ${ }^{1}$ D.M.S. Mardani ${ }^{2}$, G.S. Hermawan ${ }^{3}$ \\ 123 Jurusan Pendidikan Bahasa Jepang, Universitas Pendidikan Ganesha, Singaraja,Bali \\ e-mail: seftya.dwita.fanani@undiksha.ac.id \\ wayan.sadyana@undiksha.ac.id satya.hermawan@undiksha.ac.id
}

\begin{abstract}
Abstrak
Penelitian ini bertujuan untuk menganalisis persepsi guru terhadap penggunaan buku ajar Nihongo Kirakira dalam pembelajaran bahasa Jepang berbasis Kurikulum 2013 di SMA kota Singaraja. Penelitian ini berjenis penelitian deskriptif dengan pendekatan kualitatif. Penelitian ini menggunakan penelitian populasi dengan responden berjumlah tujuh guru mata pelajaran bahasa Jepang yang menggunakan buku ajar Nihongo Kirakira dalam pembelajaran bahasa Jepang berbasis Kurikulum 2013 di SMA kota Singaraja. Teknik pengumpulan data yang digunakan adalah teknik kuesioner dan wawancara. Data dari teknik kuesioner dan wawancara dijabarkan secara kualitatif. Hasil dari penelitian ini yaitu seluruh guru memiliki persepsi yang sangat baik terhadap penggunaan buku ajar Nihongo Kirakira dalam pembelajaran bahasa Jepang berbasis Kurikulum 2013. Hal ini menunjukkan bahwa buku ajar Nihongo Kirakira dinilai memenuhi karakteristik Kurikulum 2013 sehingga dapat digunakan dalam pembelajaran bahasa Jepang berbasis Kurikulum 2013. Karakteristik Kurikulum 2013 dalam buku ajar Nihongo Kirakira terlihat dari kesesuaian materi ajar dengan silabus Kurikulum 2013, memiliki pembelajaran yang berbasis pendekatan saintifik, menggunakan model pembelajaran yang berpusat pada siswa dan media pembelajaran berbasis ICT serta memunculkan kompetensi dasar siswa.
\end{abstract}

Kata kunci : Persepsi guru, Nihongo Kirakira, Kurikulum 2013

\section{要旨}

本研究の目的はシンガラジャ市に高等学校における2013年カリキュラムに基づく『日本語 キラキラ』の教科書の利用に対する教師の評価を明らかにすることである。調査対象はシン ガラジャ市の高等学校『日本語キラキラ』を利用している日本語教師（７名）である。デー タはアンケート、インタビューによって収集し、定性的に分析した。結果、2013年カリキュ ラムに基づく日本語授業にての『日本語キラキラ』という教科書の利用に対する教師の評価 は非常に良いことが分ける。つまり、『日本語キラキラ』という教科書は2013年カリキュラ ムに基づく授業に利用するのが適切であることも言える。『日本語キラキラ』という教科書 における 2013 年カリキュラムの特徽は教科書における教材は2013年カリキュラムのシラバス 科学的アプローチに基づい、学習モデルは学生中心で、情報通信技術による学習のメディ アを使用た、学習者の基本的の基礎的な学習目標の日本語能力を向上させることを示す。

キーワード : 教師の評価、『日本語キラキラ』、2013年カリキュラムの方針 


\section{Pendahuluan}

Kurikulum 2013 adalah kurikulum terbaru yang merupakan hasil dari penyempurnaan kurikulum sebelumnya yaitu Kurikulum Berbasis Kompetensi (KBK) dan Kurikulum Tingkat Satuan Pendidikan 2006 (KTSP 2006). Perubahan kurikulum sebagai aspek fundamental dalam dunia pendidikan tentunya membawa perubahan pada komponenkomponen pendidikan yang lainnya. Adapun Kurniasih dan Sani (dalam Inabah, 2015:2) menyebutkan perubahan-perubahan dari kurikulum sebelumnya yang terdapat dalam kurikulum 2013 antara lain adalah; (1) perubahan standar kompetensi lulusan (SKL), (2) perubahan standar isi, (3) perubahan standar proses dan (4) perubahan standar evaluasi.

Menghadapi berbagai perbedaan tersebut, dilakukan langkah penguatan tata kelola pembelajaran diantaranya dengan cara menyiapkan buku pegangan pembelajaran yang terdiri dari buku siswa dan buku guru serta menyiapkan guru supaya memahami pendayagunaan sumber belajar yang telah disiapkan dan sumber lain yang dapat mereka manfaatkan (Mulyasa, 2013:168).

Berkaitan dengan hal tersebut, The Japan Foundation selaku badan hukum khusus dan lembaga independen di bawah naungan Kementerian Luar Negeri Jepang yang bertugas mengenalkan budaya Jepang, pengembangan pendidikan bahasa Jepang dan pertukaran intelektual serta pengembangan studi Jepang menyusun suatu buku ajar bahasa Jepang bagi SMA/MA berbasis Kurikulum 2013 revisi 2016 yang diberi judul "Nihongo Kirakira". Buku ajar Nihongo Kirakira yang disusun oleh The Japan Foundation dirancang sedemikian rupa agar sesuai dengan kehidupan siswa SMA/MA di Indonesia. Pembelajaran dalam buku tersebut mengasah keterampilan hidup di abad 21. Yaitu kolaborasi, komunikasi, kreativitas, berpikir kritis dan cakap literasi.

Berdasarkan hasil studi pendahuluan pada 6 SMA di kota Singaraja, yaitu; SMA Negeri 2 Singaraja, SMA Negeri 3 Singaraja, SMA Negeri 4 Singaraja, SMA Laboratorium UNDIKSHA, SMA Karya Wisata, dan SMA Saraswati Singaraja yang telah menerapkan Kurikulum 2013, 5 sekolah diantaranya telah menggunakan buku ajar Nihongo Kirakira sebagai acuan dalam pembelajaran bahasa Jepang berbasis Kurikulum 2013. Diketahui pula bahwa penerapan Kurikulum 2013 di SMA kota Singaraja telah dimulai pada tahun 2013 oleh SMA Negeri dan pada tahun 2016 oleh SMA Swasta. Sedangkan, buku ajar Nihongo Kirakira diterbitkan pada tahun 2017. Sebelum buku ajar Nihongo Kirakira diterbitkan, guru bahasa Jepang SMA di kota Singaraja menggunakan buku ajar lama berbasis KTSP 2006 yang tidak relevan dengan kebutuhan Kurikulum 2013.

Fenomena peralihan buku ajar lama ke buku ajar baru ini memunculkan segala bentuk persepsi. Persepsi inilah yang dibutuhkan untuk dapat mengetahui penggunaan buku ajar Nihongo Kirakira dalam pembelajaran bahasa Jepang berbasis Kurikulum 2013. Mengingat, masih terdapat beberapa guru bahasa Jepang di Singaraja yang memilih untuk tidak menggunakan buku ajar Nihongo Kirakira. Guru tersebut menilai kebutuhan pembelajaran bahasa Jepang berbasis Kurikulum 2013 dapat terpenuhi dengan menggunakan buku ajar lama.

Fenomena tersebut dipandang sebagai suatu fenomena yang menarik untuk diteliti lebih lanjut. Penelitian ini penting untuk dilakukan karena persepsi guru terhadap penggunaan buku ajar Nihongo Kirakira dapat mempengaruhi pola sikap, usaha dan motivasi guru dalam kegiatan mengajar. Persepsi juga dapat memberikan gambaran tentang keberadaan dan penerimaan buku ajar Nihongo Kirakira di dalam paradigma baru pendekatan pembelajaran. Selain itu hasil dari penelitian ini dapat dijadikan sebagai bahan rujukan dalam memilih buku ajar bagi guru yang belum menggunakan buku ajar berbasis Kurikulum 2013.

Penelitian tentang persepsi guru terhadap penggunaan buku ajar pernah dilakukan oleh Farooqui (2008). Berdasarkan hasil penelitian tersebut, diketahui bahwa terjadi kesenjangan persepsi guru terhadap penggunaan buku teks. Sama halnya dengan penelitian terdahulu, penelitian ini diharapkan mampu memberikan temuan bermanfaat terkait persepsi guru terhadap penggunaan buku teks terutama buku ajar Nihongo Kirakira dalam pembelajaran bahasa Jepang berbasis Kurikulum 2013. 


\section{Metode \\ Metode Pengumpulan Data}

Penelitian ini menggunakan jenis metode penelitian deskriptif dengan pendekatan kualitatif. Data dalam penelitian ini diperoleh melalui dua cara yaitu kuesioner dan wawancara. Hasil dari penelitian ini hanya mendeskripsikan tentang hasil rata-rata hitung data kuesioner dan wawancara terhadap subjek penelitian. Sehingga dapat memberikan gambaran tentang persepsi guru terhadap penggunaan buku ajar Nihongo Kirakira dalam pembelajaran bahasa Jepang berbasis Kurikulum 2013 di SMA kota Singaraja. Teknik pengumpulan data dalam penelitian ini menggunakan teknik kuesioner tertutup dan wawancara terstruktur. Kuesioner tertutup digunakan untuk memilih tingkat kesetujuan guru terhadap suatu pernyataan mengenai penggunaan buku ajar Nihongo Kirakira yang telah ditentukan. Sehingga pendapat responden tentang penggunaan buku ajar Nihongo Kirakira dapat diketahui secara objektif. Wawancara terstruktur dipilih sebagai teknik pengumpulan data dalam penelitian ini agar informasi yang diperoleh dari informan lebih fokus pada topik wawancara. Sehingga keterangan atau informasi yang didapat dapat memperkuat data sebelumnya yang diperoleh dengan menggunakan teknik kuesioner.

Sebelum menyusun pernyataan dalam kuesioner dan wawancara, definisi konsep dan definisi operasional perlu ditetapkan untuk menentukan indikator yang akan diukur. Indikator tersebut kemudian dijabarkan dalam bentuk pernyataan yang tercantum dalam lembar kuesioner. Definisi konsep dan definisi operasional dalam instrumen penelitian ini disusun berdasarkan pada karakteristik buku ajar Nihongo Kirakira yang relevan dengan tujuan Kurikulum 2013. Karakteristik tersebut tercantum pada bagian lembar persembahan di setiap buku ajar Nihongo Kirakira. Definisi operasional tersebut selanjutnya digunakan sebagai acuan penyusunan indikator kisi-kisi instrument penelitian.

Dalam menganalisis data yang diperoleh, digunakan teknik analisis data deskriptif kualitatif. Pada penelitian ini butir-butir pernyataan yang ditanggapi oleh subjek akan diukur menggunakan perhitungan statistika sederhana dengan skala pengukuran Likert. Data yang diperoleh kemudian dicatat dan dikategorikan sesuai dengan interval yang sudah ditentukan. Hasil pengkategorian data diiterpretasi sesuai ketentuan sebagai berikut :

Tabel 1. Interpretasi Hasil Data
\begin{tabular}{|c|c|}
\hline Interval & Kategori \\
\hline $3,26-4,00$ & Sangat Baik \\
\hline $2,51-3,25$ & Baik \\
\hline $1,76-2,50$ & Tidak Baik \\
\hline $1,00-1,75$ & $\begin{array}{c}\text { Sangat Tidak } \\
\text { Baik }\end{array}$ \\
\hline
\end{tabular}

Selanjutnya, data hasil kuesioner dijabarkan ke dalam bentuk deskripsi menggunakan hasil analisis dan reduksi data wawancara.

\section{Hasil dan Pembahasan}

Berdasarkan hasil penelitian, diketahui bahwa dari hasil pengisian angket secara keseluruhan guru memiliki persepsi yang sangat baik terhadap penggunaan buku ajar Nihongo Kirakira dalam pembelajaran bahasa Jepang berbasis Kurikulum 2013. Secara keseluruhan, rata-rata hitung yang diperoleh sebesar 3.59. Hal tersebut menunjukkan bahwa hampir seluruh aspek dan indikator dalam kuesioner dipersepsikan sangat baik oleh guru.

\section{Persepsi Guru terhadap Kesesuaian Materi Buku Ajar dengan Silabus Kurikulum 2013 Revisi 2016}


(Trianto,2010:96) menyatakan bahwa silabus merupakan rencana pembelajaran pada suatu dan/atau kelompok mata pelajaran atau tema tertentu yang mencakup Standar Kompetensi, Kompetensi Dasar, materi pokok/pembelajaran,kegiatan pembelajaran, indikator, pencapaian kompetensi untuk penilaian, alokasi dan sumber belajar. Silabus yang ditetapkan pada pendidikan di Indonesia saat ini adalah silabus yang memuat konsep Kurikulum 2013. Guru memiliki persepsi yang sangat baik terhadap kesesuaian materi buku ajar Nihongo Kirakira dengan silabus Kurikulum 2013 Revisi 2016. Rerata hitung yang diperoleh sebesar 3,45 dengan kategori sangat baik. Materi dalam buku ajar Nihongo Kirakira dinilai sesuai dengan Kurikulum 2013 revisi 2016 karena memenuhi kriteria indikator sebagai buku ajar yang sesuai dengan pemberlakuan Kurikulum 2013, menunjang proses pembelajaran bahasa Jepang berbasis Kurikulum 2013 menjadi lebih mudah dan terarah, mempermudah penyusunan RPP dan sesuai dengan kebutuhan siswa. Buku ajar Nihongo Kirakira dinilai telah memuat Kompetensi Inti dan Kompetensi Dasar (KD) yang sesuai dengan Permendikbud tahun 2016 Nomor 24 tentang silabus Kurikulum 2013 untuk mata pelajaran bahasa Jepang, memiliki arah pembelajaran yang jelas dan sesuai dengan level pembelajar tingkat SMA.

Salah satu indikator yang tidak terpenuhi dalam aspek ini adalah keruntutan penyusunan materi secara tematik sesuai dengan silabus Kurikulum 2013. Guru menilai bahwa penyajian materi tidak sesuai dengan urutan Kompetensi Dasar (KD) yang telah ditetapkan pada Permendikbud. Untuk mengatasi kendala tersebut, guru mengatur ulang dan menyesuaikan urutan materi dalam buku ajar Nihongo Kirakira dengan urutan Kompetensi Dasar (KD) yang telah ditetapkan pada Permendikbud. Selain itu terdapat salah satu guru yang memiliki persepsi tidak baik terhadap kesesuaian buku ajar Nihongo Kirakira dengan kebutuhan siswa karena buku ajar Nihongo Kirakira dinilai kurang memuat pengetahuan tentang objek pariwisata Indonesia. Alasan tersebut dapat dipengaruhi oleh lingkungan dimana guru mengajar. Sebagaimana yang diungkapkan oleh Richardson (dalam Rosyida,2016) tentang persepsi guru terhadap suatu objek dalam kegiatan pembelajaran. Persepsi guru dapat dipengaruhi oleh latar belakang pendidikan guru, lamanya pengalaman mengajar, siapa yang diajar, dimana guru mengajar, apa yang diajarkan dan lain-lain. Sekolah tempat guru tersebut mengajar adalah SMA yang implementasi pembelajarannya cenderung mengacu pada karakteristik SMA plus. SMA plus memiliki karakteristik implementasi kurikulum komprehensif ditambah pelatihan keterampilan khusus. SMA tempat guru tersebut mengajar, menjalankan kurikulum sesuai aturan Kemendikbud ditambah pelatihan keterampilan yang berorientasi pada pengembangan keahlian di bidang pariwisata. Akibatnya, orientasi berpikir guru tentang tujuan pembelajaran bahasa Jepang cenderung mengarah kepada pengembangan keahlian berbahasa Jepang di bidang pariwisata. Sehingga, motivasi mengajar dan tindak laku guru juga beriorientasi pada kebutuhan pembelajaran pariwisata. Hal ini lah yang menyebabkan guru tersebut merasa bahwa buku ajar Nihongo Kirakira tidak sesuai dengan kebutuhan siswa.

\section{Persepsi Guru terhadap Kesesuaian penyajian Alur Pembelajaran Sesuai dengan Pendekatan Saintifik}

Menurut Sufairoh (116:2016) pendekatan saintifik adalah proses pembelajaran yang dirancang sedemikian rupa agar peserta didik secara aktif mengkonstruk konsep, hukum atau prinsip melalui tahapan-tahapan mengamati (untuk mengidentifikasi atau menemukan masalah), merumuskan masalah, mengajukan atau merumuskan hipotesis, mengumpulkan data dengan berbagai teknik, menganalisis data, menarik kesimpulan, dan mengkomunikasikan konsep, hukum atau prinsip yang "ditemukan". Pendekatan saintifik yang dimunculkan dalam buku ajar Nihongo Kirakira adalah pendekatan saintifik 5M. Guru memiliki persepsi yang sangat baik terhadap kesesuaian penyajian alur pembelajaran sesuai dengan pendekatan saintifik $5 \mathrm{M}$. Berdasarkan hasil data penelitian, rerata hitung yang diperoleh sebesar 3,79. Materi dalam buku ajar Nihongo Kirakira dinilai sesuai dengan Kurikulum 2013 revisi 2016 karena memenuhi kriteria indikator sebagai buku ajar yang 
memiliki alur pembelajaran sesuai dengan pendekatan saintifik $5 \mathrm{M}$, mendukung siswa untuk memperoleh pengetahuan baru melalui proses ilmiah, memiliki materi yang berkesinambungan, memiliki tema pembelajaran yang dekat dengan kehidupan siswa serta memunculkan pengembangan nilai-nilai karakter dalam penyajian materi pembelajaran.

Buku Nihongo Kirakira memiliki konsep pembelajaran yang dapat dikonstruk dengan baik oleh siswa karena kegiatan mengamati, menanya, mencoba, menalar, dan mengkomunikasikan yang sesuai dengan standar pendekatan saintifik $5 \mathrm{M}$ sudah jelas terstruktur di dalam buku ajar Nihongo Kirakira. Adapun alur atau proses pembelajaran saintifik $5 \mathrm{M}$ yang dimunculkan dalam buku ajar Nihongo Kirakira diawali dengan kegiatan mengamati, kemudian dilanjutkan dengan kegiatan menanya, mencoba, mengasosiasi dan mengkomunikasikan. Kegiatan mengamati terbagi menjadi tiga kegiatan yaitu kegiatan mengarahkan konsentrasi siswa pada topik dan target pembelajaran (mite kangaemashou), memperkenalkan kosa kata baru (kiite iimashou), dan melatih penyebutan kosa kata (nihongo de iimashou). Kegiatan menanya dilakukan dengan memperkenalkan ungkapan dalam percakapan (kikimashou). Dalam kegiatan kikimashou biasanya siswa akan diberikan lembar kerja untuk dikerjakan dengan teman sebangku atau diskusi kelompok. Kegiatan mencoba dilakukan dengan melatih percakapan (hanashimashou). Melatih percakapan biasanya dilakukan antar siswa, antar kelompok siswa atau antar siswa dengan guru. Kegiatan mengasosiasi terdiri dari kegiatan mengidentifikasi huruf dan memperoleh informasi yang dibutuhkan (yomimashou), menyimpulkan fungsi ungkapan dan struktur kalimat, mempelajari struktur kalimat (kotoba no benkyou), menelaah budaya (bunka), serta merangkum materi yang telah dipelajari. Sedangkan untuk kegiatan mengkomunikasikan dilakukan dengan kegiatan mengaplikasikan materi yang dihubungkan dengan keadaan lingkungan sekitar (kegiatan atau proyek) serta melatih menulis dan membuat karangan (kakimashou).

Selaras dengan penerapan pembelajaran saintifik $5 \mathrm{M}$, buku ajar Nihongo Kirakira juga memuat kompetensi abad ke-21 yaitu 4C (critical thinking, communication, collaboration, dan creativity). Dalam buku ajar Nihongo Kirakira, kemampuan critical thinking atau berpikir kritis dikembangkan melalui kegiatan mite kangaemasu dan bunka. Dalam kegiatan mite kangaemasu siswa diarahkan untuk dapat berkonsentrasi dan memiliki gambaran terhadap tema atau target pembelajaran yang akan dipelajari. Siswa distimulus dengan pertanyaan-pertanyaan yang dapat melatih siswa berpikir kritis, analitis dan logis. Pertanyaan-pertanyaan stimulus tersebut misalnya terdapat dalam kegiatan mite kangaemasu pada bab 14 tentang pekerjaan rumah yaitu "apa yang sebaiknya dilakukan agar kehidupan di rumah terasa nyaman?". Selain itu pada kegiatan bunka, siswa distimulus dengan pertanyaan-pertanyaan untuk dapat memberikan gambaran tentang perbedaan budaya Jepang dan Indonesia serta mencari nilai-nilai positif dari kedua budaya tersebut. Pertanyaan stimulus tersebut misalnya terdapat pada bab 15 tentang lingkungan rumah yaitu "rumah tradisional Indonesia terbuat dari apa? Mengapa begitu?".

Kemampuan komunikasi salah satunya dapat dikembangkan melalui kegiatan proyek. Dalam kegiatan proyek, siswa diminta untuk mempresentasikan hasil proyeknya di depan kelas. Dalam melakukan presentasi, siswa dilatih untuk dapat berkomunikasi secara baik yaitu dapat memahami konteks yang akan dikomunikasikan, percaya diri untuk melakukan komunikasi verbal, bersikap positif dalam berdiskusi dan lain sebagainya.

Kemampuan kolaborasi dikembangkan melalui kegiatan mite kangaemashou, proyek, dan bunka. Ketiga kegiatan tersebut diwujudkan melalui diskusi dan kerja kelompok. Dalam diskusi dan kerja kelompok, terdapat pembagian tugas, mengumpulkan ide-ide baru, membangun sikap tanggung jawab dan bekerjasama yang baik sehingga kemampuan kolaborasi dapat dikembangkan.

Kemampuan kreativitas dikembangkan melalui kegiatan proyek dan kakimashou (melatih menulis dan mengarang). Dalam kegiatan tersebut siswa dituntut untuk dapat mengembangkan ide-ide baru (inovatif) dan mengasah kreativitasnya. Siswa dilatih untuk memiliki motivasi untuk menciptakan gagasan dan konsep baru serta mengolah gagasan tersebut menjadi sesuatu yang menarik menggunakan kemampuan kreativitasnya. 
Salah satu tujuan diterapkannya pendekatan saintifik adalah agar peserta didik dapat memperoleh pengetahuan baru melalui proses ilmiah. Sebagaimana yang dipaparkan oleh Kemendikbud bahwa pendekatan ilmiah (saintifik) merupakan pendekatan yang merujuk pada teknik-teknik investigasi atas fenomena atau gejala, memperoleh pengetahuan baru, atau mengoreksi dan memadukan pengetahuan sebelumnya. Penggunaan buku ajar Nihongo Kirakira dalam pembelajaran bahasa Jepang dinilai dapat mengembangkan rasa ingin tahu siswa melalui proses ilmiah/investigasi. Materi di dalam buku ajar Nihongo Kirakira disusun dari mudah ke sulit sehingga siswa dapat belajar secara sistematis dan terstruktur. Buku ajar Nihongo Kirakira memiliki tema-tema pembelajaran yang sangat dekat dengan kehidupan siswa. Hal tersebut dibuktikan dengan gambar-gambar ilustrasi yang terdapat dalam buku ajar Nihongo Kirakira dapat mewakili kegiatan yang biasa dilakukan siswa sehari-hari. Selain itu, kosa kata yang dimunculkan dalam buku ajar Nihongo Kirakira merupakan kosa kata yang biasa mudah ditemukan di sekitar siswa.

\section{Persepsi Guru Terhadap Penggunaan Model, Metode dan Strategi Pembelajaran Yang Beragam Sesuai dengan Tujuan Pembelajaran Kurikulum 2013}

Salah satu orientasi pembelajaran dalam Kurikulum 2013 adalah keterampilan hidup di abad-21. Berdasarkan analisis dan sintetis dari 20 literatur, ditemukan bahwa keterampilan hidup abad ke-21 menekankan keterampilan berpikir tingkat tinggi, keterampilan berkomunikasi, dan keterampilan bekerjasama (Susiana, 2014). Dalam keterampilan hidup di abad ke-21 siswa dituntut untuk memiliki kemampuan berpikir tingkat tinggi atau yang biasa dikenal dengan HOTS (Higher Order of Thingking Skill). Permendikbud No 22 tahun 2016 tentang standar isi menjelaskan 14 prinsip pembelajaran. Beberapa diantara prinsip-prinsip tersebut mengarah pada pembelajaran HOTS. Sehingga, model, metode dan strategi pembelajaran yang diterapkan dalam pembelajaran berbasis Kurikulum 2013 harus dapat mengarahkan siswa memiliki HOTS.

Guru memiliki persepsi yang sangat baik terhadap buku ajar Nihongo Kirakira sebagai buku ajar yang dapat mendukung penggunaan model, metode dan strategi pembelajaran yang beragam sesuai dengan tujuan pembelajaran Kurikulum 2013. Rerata hitung yang diperoleh adalah sebesar 3,45 dengan kategori sangat baik. Guru menilai bahwa secara umum penyajian konsep pembelajaran dalam buku ajar Nihongo Kirakira berbasis pada siswa atau student based learning serta media berbantuan teknologi. Model pembelajaran yang dimunculkan dalam buku ajar Nihongo Kirakira diantaranya adalah Discovery Learning, Inquiry Learning, dan Project Based Learning. Ketiga model mengajar yang dimunculkan dalam buku ajar Nihongo Kirakira tersebut relevan dengan kebutuhan Kurikulum 2013 karena dapat meningkatkan kemampuan berpikir kritis, kreatif dan inovatif siswa. Sebagai mana dimaksud pada Permendikbud Nomor 103 tahun 2014 dan Permendikbud Nomor 22 tahun 2016 tentang model pembelajaran Kurikulum 2013. Model pembelajaran Kurikulum 2013 yaitu model pembelajaran yang menonjolkan aktivitas dan kreativitas, menginspirasi, menyenangkan dan berprakarsa, berpusat pada siswa, otentik, kontekstual dan bermakna bagi kehidupan siswa sehari-hari,

Strategi pemebelajaran yang digunakan dalam rangkaian kegiatan pembelajaran menggunakan buku ajar Nihongo Kirakira adalah strategi pembelajaran inquiry. Strategi ini digunakan oleh guru untuk mengarahkan siswa pada proses berpikir secara kritis dan analitis untuk mencari dan menemukan sendiri pemahamannya terhadap suatu pengetahuan. Metode pembelajaran yang relevan dengan strategi pembelajaran inquiry serta sering diterapkan oleh guru dalam pembelajaran menggunakan buku ajar Nihongo kirakira adalah metode diskusi, drill, role play, demonstrasi dan tanya jawab.

Guru menyatakan bahwa sebenarnya metode pembelajaran tersebut sudah diterapkan sebelum terbentuknya Kurikulum 2013. Namun metode yang lebih banyak digunakan adalah metode konvensional yang mengutamakan ceramah dan menghafal. Pada pembalajaran berbasis Kurikulum 2013, guru membatasi penerapan metode konvensional seperti metode ceramah. Sebaliknya guru menambah kuantitas penerapan metode role play, diskusi, drill dan metode pembelajaran lain yang relevan dengan kebutuhan Kurikulu 2013. 


\section{Persepsi Guru terhadap Kompetensi Sikap, Pengetahuan dan Keterampilan yang Dimunculkan dalam Buku Ajar Nihongo Kirakira}

Kurikulum 2013 adalah langkah lanjutan dan pembaharuan dari pengembangan kurikulum sebelumnya dengan cakupan standar kompetensi berupa kompetensi sikap, pengetahuan dan keterampilan secara terpadu. Secara umum, guru memiliki persepsi yang sangat baik terhadap penggunaan buku ajar Nihongo Kirakira sebagai buku ajar yang memunculkan kompetensi sikap, pengetahuan dan keterampilan dalam materi pembelajarannya. Rerata hitung yang diperoleh adalah sebesar 3,67 dengan kategori sangat baik. Dalam buku ajar Nihongo Kirakira, kompetensi sikap diwujudkan dalam kompetensi sosial. Kompetensi pengetahuan dan keterampilan dirumuskan dalam Kompetensi Inti (KI) yang dijabarkan lagi dalam Kompetensi Dasar (KD).

Guru menilai penggunaan buku ajar Nihongo Kirakira sebagai buku ajar yang materinya dapat digunakan guru untuk mengarahkan peserta didik agar memiliki sikap-sikap luhur. Bagian dari buku ajar Nihongo Kirakira yang mengarahkan siswa untuk memiliki sikap peduli (toleran dan damai) dicontohkan dalam kegiatan mite kangaemasu dan bunka. Dalam kegiatan mite kangaemasu dan bunka siswa dibimbing untuk dapat memahami perbedaan budaya antara budaya Jepang dan budaya Indonesia, berbagi informasi antar sesama siswa tentang budaya dari setiap daerah di Indonesia serta menganalisis hal-hal positif dari budaya Jepang dan budaya Indonesia. Guru juga menilai bahwa materi dalam buku ajar Nihongo Kirakira sesuai dengan kompetensi pengetahuan karena bersifat faktual, konseptual, prosedural dan metakognitif. Buku ajar Nihongo Kirakira memiliki materi pelajaran yang dekat dengan kehidupan siswa serta berisi contoh-contoh nyata yang dapat ditemui secara langsung dalam kehidupan sehari-hari. Sebagai contoh, pada bab 14 yang materi pelajarannya berkaitan dengan kegiatan membantu pekerjaan rumah terdapat kosa kata baru dan ilustrasi tentang berbagai pekerjaan rumah yang secara faktual memang sering dilakukan oleh siswa di rumah. Terdapat kegiatan mengklasifikasikan dan menggeneralisasi suatu informasi secara konseptual melalui kegiatan nihongo de iimashou. Pembentukan konsep melalui kegiatan klasifikasi misalnya mengklasifikasikan jenis pekerjaan di luar rumah, pekerjaan berat dan pekerjaan yang sering dilakukan. Untuk memiliki pengetahuan prosedural, siswa diarahkan untuk membuat suatu proyek dan menghasilkan suatu produk. Kegiatan melakukan proyek dilengkapi dengan panduan prosedural sehingga siswa dapat mengkonstruk pengetahuan dengan langkah-langkah prosedural yang jelas. Pemerolehan pengetahuan metakognitif salah satunya diwujudkan dengan pengetahuan diri (self knowledge). Dalam buku ajar Nihongo Kirakira, pengetahuan diri (self knowledge) dapat dilakukan melalui kegiatan penilaian diri. Penilaian diri berfungsi untuk mengetahui kekuatan dan kelemahan diri siswa sehingga siswa dapat menentukan sendiri strategi yang paling tepat bagi dirinya.

\section{Simpulan dan Saran}

Berdasarkan penelitian ini dapat diketahui bahwa guru memiliki persepsi yang sangat baik terhadap karakteristik Kurikulum 2013 dalam penggunaan buku ajar Nihongo Kirakira. Guru menilai bahwa buku ajar Nihongo Kirakira memuat karakteristik Kurikulum 2013 yang dapat membantu guru melaksanakan pembelajaran bahasa Jepang berbasis Kurikulum 2013. Adapun komponen karakteristik Kurikulum 2013 dalam buku ajar Nihongo Kirakira yang dipersepsikan sangat baik adalah kesesuaian materi buku ajar dengan silabus Kurikulum 2013 revisi 2016, kesesuaian penyajian alur pembelajaran dengan pendekatan saintifik, mendukung penggunaan model dan metode pembelajaran yang beragam sesuai dengan tujuan pembelajaran berbasis Kurikulum 2013, serta memunculkan kompetensi sikap, pengetahuan dan keterampilan.

Terdapat beberapa saran untuk pihak-pihak terkait berdasarkan penelitian yang telah dilakukan. Terkait dengan penggunaan buku ajar Nihongo Kirakira sebagai buku ajar yang relevan dengan kebutuhan Kurikulum 2013, sebagian guru mengalami kendala pada 
penyediaan buku ajar Nihongo Kirakira bagi siswa. Sekolah sebaiknya mendukung penyediaan buku ajar Nihongo Kirakira bagi siswa agar pembelajaran bahasa Jepang berbasis Kurikulum 2013 dapat terlaksana secara maksimal. Selain itu, guru sebaiknya lebih aktif melakukan kegiatan sharing tentang penggunaan buku ajar Nihongo Kirakira dalam forum MGMP. Agar pengetahuan guru terkait penggunaan buku ajar Nihongo Kirakira dapat lebih beragam guna tercapainya tujuan pembelajaran yang lebih baik. Bagi guru yang masih menggunakan buku ajar lama dalam pembelajaran bahasa Jepang berbasis Kurikulum 2013 dan memilih untuk tidak menggunakan buku ajar yang lebih relevan disarankan untuk segera menggunakan buku ajar Nihongo Kirakira karena buku ajar Nihongo Kirakira telah disusun berdasarkan kebutuhan Kurikulum 2013 dan dipersepsikan sangat baik oleh guru yang telah menggunakannya.

\section{Daftar Pustaka}

Khanifah Inabah. 2015. Pengaruh Pemakaian Buku Teks Pelajaran Kurikulum 2013 terhadap Efektivitas Pembelajaran Pendidikan Agama Islam dan Budi Pekerti Kelas X SMA Negeri 1 Yogyakarta. Skripsi (tidak diterbitkan). Jurusan Pendidikan Agama Islam, UIN Sunan Kalijaga Yogyakarta.

Mulyasa, E. 2013. Pengembangan dan Implementasi Kurikulum 2013, Bandung : Remaja Rosdakarya.

Rosyida Elvira M.R. 2016. Teachers' Perceptions Toward the Use of English Text Book. Jurnal. STKIP Muhammadiyah Pringsewu

Sufairoh. 2016. Pendekatan Saintifik dan Model Pembelajaran K-13. Jurnal. SMP Negeri 1 Malang

Sugiyono, 2007. Metode Pebelitian Kuantitatif, Kualitatif dan R\&D. Bandung : Alfabeta

Susiana, Nancy. 2014. "Implementasi Keterampilan Abad 21 dalam Kurikulum 2013" Makalah disajikan dalan Integrasi Keterampilan Abad 21 dalam Kurikulum 2013 untuk Mewujudkan Indonesia Jaya. STKIP Surya. Tangerang 15 Februari 2014

Trianto, 2010. Model Pembelajaran Terpadu. Jakarta : Bumi Aksara 